\title{
Dump Sites Location and its Health Implications within the Polytechnic, Ibadan using Geographical Information System Approach
}

\author{
Fatunmibi, Oluwagbemiga ${ }^{1}$, Gbopa, Adetola Olufunmilayo ${ }^{2}$ \\ ${ }^{1,2}$ Depatment of Surveying and Geoinformatics, The Polytechnic, Ibadan, Nigeria. \\ Corresponding Author: Fatunmibi, Oluwagbemiga
}

\begin{abstract}
This study examines the distribution of dump sites within The Polytechnic, Ibadan, Nigeria. IKONOS Satellite imagery was acquired and processed for proper identification of the existing dump sites. Field data were acquired using Global Positioning System (Garmin GPS 72 csx). Image and data processing as well as database creation was done using ArcGIS 10.5 (Arcmap 10.5). Legal and illegal dump sites were identified and mapped out and as well as the proximity of the dump sites to roads, residential areas and waterways in the study area were determined. Composite map and spatial analysis map queries were produced. From the result, it shows that eleven (11) legal dump sites and twenty four (24) illegal dump sites were within the study area. World standards on dump sites conformity were considered. From the result in the study area, it shows that there are more illegal dump sites than legal dump sites. Based on proximity of the dump sites to the roads, waterways and built up areas, many of the dump site were very close to buildings where they only not destroy the aesthetic value of the areas but also constitute breeding grounds for vectors like flies, rodents, mosquitoes, which transmit diseases like typhoid fever, malaria, cholera and laser fever which are part of the killer diseases in Nigeria and most of the African countries. Therefore, the study recommends that more legal dump sites should be created and monitored in the study area, most especially in the Northern parts the study area since the population there is high. Also, students as well as staff should be well educated on the risk associated with indiscriminate refuse disposal.
\end{abstract}

Keywords: Dump, Satellite imagery, World standards, Spatial analysis, Conformity, Vectors

\section{INTRODUCTION}

One of the biggest problems that the entire world is facing is disposal of waste. In man's everyday life, he produces waste materials which, if not properly managed, can lead to health and environmental problems. Virtually all aspects of man's productive activities involve the generation of waste ${ }^{[1]}$. Wastes can be classified into three major groups based on their sources and composition namely; solid, liquid and gaseous. Solid waste occupies a geographical space. It does not decompose easily, and also does not evaporate like the gaseous waste. This work is concerned with solid waste. Solid waste can be classified based on composition, source, as well as physico-chemical properties. Waste is defined as any unwanted material that is due for discarding. Waste is any unavailable material arising from an individual, domestic, occupational, and industrial or any human activity (which has no economic value) for disposal ${ }^{[2]}$. Waste can also be defined as any substances which require being disposed of. Among all the wastes (solid, liquid and gas), solid waste is the most popular and most difficult to manage locally because it does not flow, evaporate, diffuse, dissolve or be absorbed into the surrounding unlike liquid and gaseous wastes [3]. Wastes come from homes, schools, hospitals, and businesses ${ }^{[4]}$. 
Dumpsites have been the most organized common methods of waste disposal and remain so in many places in the world ${ }^{[5]}$. In developing countries like the Federal Republic of Nigeria, the prevailing practice of municipal solid waste disposal is to dispose of the solid waste in dumpsites ${ }^{[6 ; 7 \text {; }}$ $5 ; 8]$.

Thousands of tons of solid waste are generated daily in African countries as stated by ${ }^{[9,10]}$. The classes of solid waste based on the source are: municipal (domestic, institutional and commercial), agricultural, mining and mineral, radioactive and industrial wastes. Among these sources, industrial and municipal wastes contribute largely to the volume of solid wastes. Due to improper solid waste disposal and collection systems, dwellers are facing serious negative environmental impacts in developing countries ${ }^{[11]}$.

Waste as infuriating as it may sound, also has its own economic benefits. In pursuit of a cleaner and healthier environment, jobs are automatically created, time, energy and land are saved, money is made and natural resources will be preserved for the future generation if the concept of Reduce, Recycle and Reuse is adopted ${ }^{[12]}$. Reduce means to decrease the numbers of material use that can increase waste production while Recycle tells about reprocessing of the waste generated to produce brand new material and reuse encourages the continual of wasted material before it is finally discarded.

The problem of waste management is even becoming more complex with the increasing rate of urbanization. The solid waste management issue in Nigerian cities is even more alarming. The volume and range of solid wastes generated daily in Nigeria have been increasing within the last few years and this is mainly due to the high population growth, urbanization, industrialization and general economic growth. About $20 \mathrm{~kg}$ of solid waste is generated per capita per annum in Nigeria that is 2.2 million tonnes yearly based on the 1989 estimated population of 110 million; the estimated volume of solid waste generated in selected urban centres in Nigeria was projected to double by the year $2000^{[13]}$.

In many Nigerian cites, the volumes of solid wastes have overwhelmed the capacity of urban administrators to manage. Only about $30-50 \%$ of generated wastes are collected in most Nigerian cities and recycling of waste is not practiced to a significant level ${ }^{[14]}$. The inadequate management of solid waste is causing a lot of problems to the local environment since these wastes are often indiscriminately dumped on open plots of land and particularly along or on streets. As a result, most urban households resort to the haphazard dumping, burn and/or burying solid waste.

Many Waste dumps are located wherever land is available irrespective of safety, health hazards and aesthetic degradation. The waste is often pilled as high as possible and sometimes burnt while in other cases, it is periodically leveled and compacted ${ }^{[15]}$.

The present situation of direct dumping of the waste without proper inspection and separation leaves a serious impact of environmental pollution causing a tremendous growth in health related problems; many cities in developing countries are facing this challenge. In recent years, there has been a phenomenal increase in the volume of wastes generated daily and many urban areas lack effective waste management systems. Zakariyau (2010) ${ }^{[16]}$ also confirmed that the proliferation of illegal waste collection sites and indiscriminate dumping of refuse at any available space has now become a common scene. Illegal dumping is a nuisance because of the physical dangers, aesthetic distaste, and costs associated with it and it may affect the health and safety of humans and wildlife. Other problems may develop if harmful substances are dumped at the site, these substances may leach into the environment and contaminate the soil and groundwater $^{[17]}$. 
Generally, open dumps provide breeding ground for pests, create health hazard, pollute the air, soil and sometimes ground and surface water as well as deteriorate the beauty of the area ${ }^{[15]}$. Some constituents of dump sites contribute majorly to most health related hazard which consequently leads to an abrupt of diseases and increasing mortality rate. Nigeria is faced with outbreaks of many diseases these days, most especially the one caused by pests and rodents that feeds on available dump site.

GIS is a computer system for capturing, storing, checking, integrating, manipulating, analyzing and displaying data related to positions on the Earth's surface. Typically, a Geographical Information System is used for handling maps of one kind or another. These might be represented as several different layers where each layer holds data about a particular kind of feature. Each feature is linked to a position on the graphical image on a map and a record in an attribute table. GIS allows us to view, understand, question, interpret, and visualize data in many ways that reveal relationships, patterns, and trends in the form of maps, globes, reports, and charts ${ }^{[18]}$. The role of Geographic Information Systems (GIS) in solid waste management is very large as many aspects of its planning and operations are highly dependent on spatial data.

In general, GIS plays a key role in maintaining account data to facilitate collection operations; customer service; analyzing optimal locations for transfer stations; planning routes for vehicles transporting waste from user to landfills; locating new landfills and monitoring the landfill. GIS is a tool that not only reduces time and cost of the site selection, but also provide a digital data bank for future monitoring program of the site ${ }^{[19]}$. The situation in The Polytechnic, Ibadan, is not different from other urban areas in Nigerian where due to poor waste management, illegal open waste dumps are found dotting the campus without any consideration to the aesthetic and health hazards due to such practice. These dumps were found indiscriminately irrespective of the presence of infrastructural facilities in such locations which are normally endangered. Therefore, this study is aimed at using Geographical Information System as an effective tool to specially examine the dump sites within The Polytechnic, Ibadan, and called for a sanitized environment that gives zero tolerate to hazard survival.

\section{MATERIALS \& METHODS Description of the Study Area}

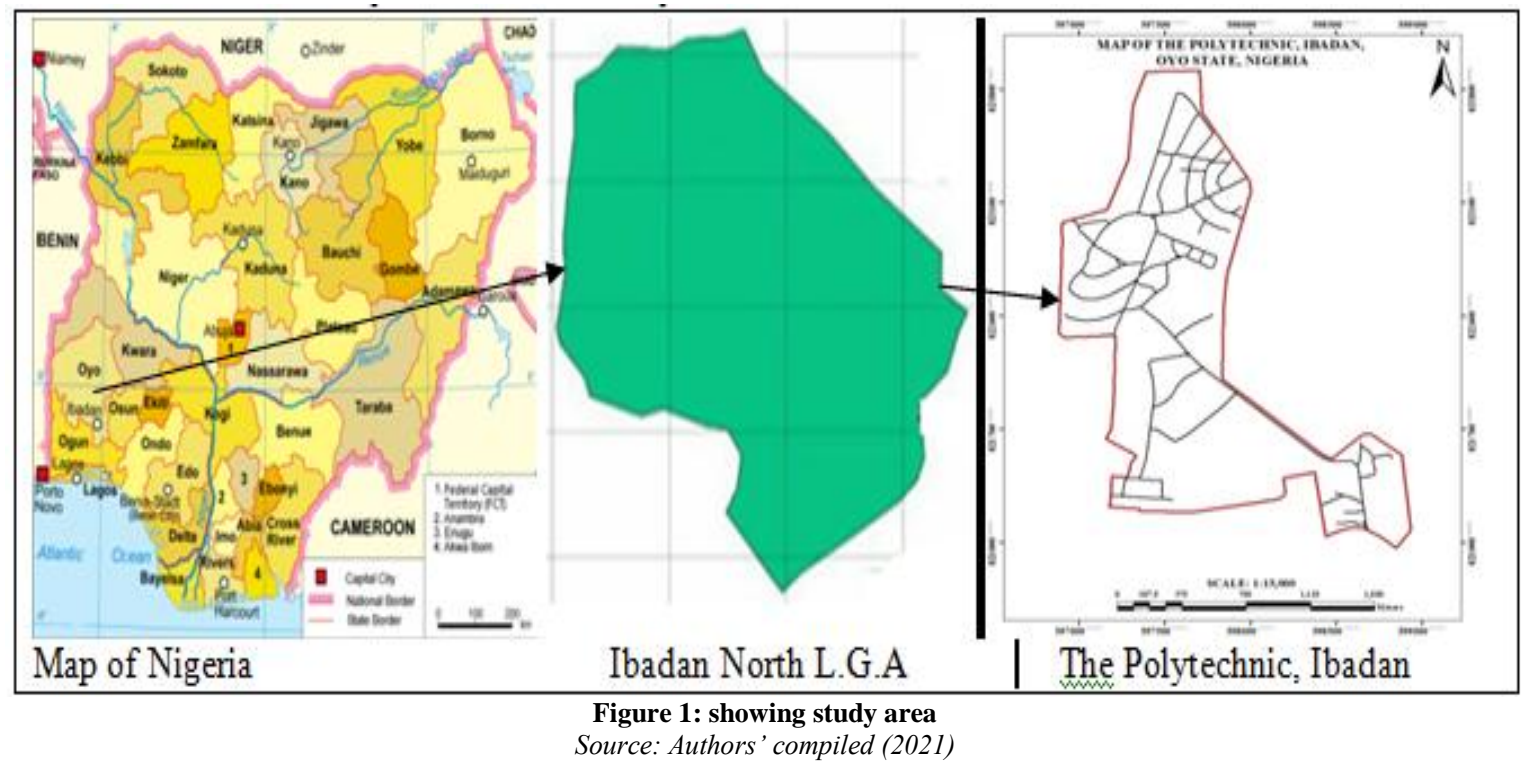


The Polytechnic, Ibadan is located along Sango-Eleyele road and also an institution of higher learning in Ibadan in Oyo State, South West Nigeria. It was founded in 1970. It lies between Latitudes $7^{0} 25^{\prime} 33^{\prime \prime} \mathrm{N}$ and $7^{0} 27^{\prime} 10^{\prime \prime} \mathrm{N}$ and Longitudes $3^{0} 53^{\prime} 35^{\prime \prime} \mathrm{E}$ and $3^{0} 52^{\prime}$ 52E. The study area covers landed area of about 245 hectares. The institution was established to provide an alternative higher education to universities, particularly in technical skill acquisition. The study area runs mainly National Diploma (ND) and Higher National Diploma (HND) programmes on full-time and part-time basis. It shares boundary with the University of Ibadan.

\section{Material used for the study}

For the purpose of this study, the following materials were used; Handheld Global Positioning System (Garmin 72csx GPS) for determining the spatial coordinates of existing dump sites, Downloaded Georeferenced IKONOS Imagery for showing the exact location of dump sites, and GIS software (ArcGIS 10.5 version) for image processing/graphic design.

\section{Method of data acquisition}

All existing dump sites were visited to ascertain their location. For the purpose of this study, both legal and illegal dump sites were considered from the study area. Handheld GPS Garmin 72csx GNSS receiver was used to acquire the spatial location coordinates $(\mathrm{x}, \mathrm{y})$ of existing dump sites. All the parameters such as the projection of the coordinate system were set in World Geodetic Survey (WGS), 1984, Universal Transverse Mercator (UTM) Zone 31N, Minna Datum.

\section{Image Digitizing and Data Processing}

Study area was clipped out from the IKONOS image. Data set projection was done in World Geodetic Survey (WGS), 1984, Universal Transverse Mercator (UTM) Zone 31N. Shape files and database were created in ArcMap 10.5 for the following features; buildings consisting of (staff quarters, lecture/classroom, security house etc), boundary, roads, rivers, and dump sites. Onscreen digitizing was done for all the created shapefiles from the imagery. The coordinates of the dumpsites obtained during the field survey were imported into the GIS software as text file, then converted to shape file to show the spatial distribution on the digital maps as well as the satellite imageries.
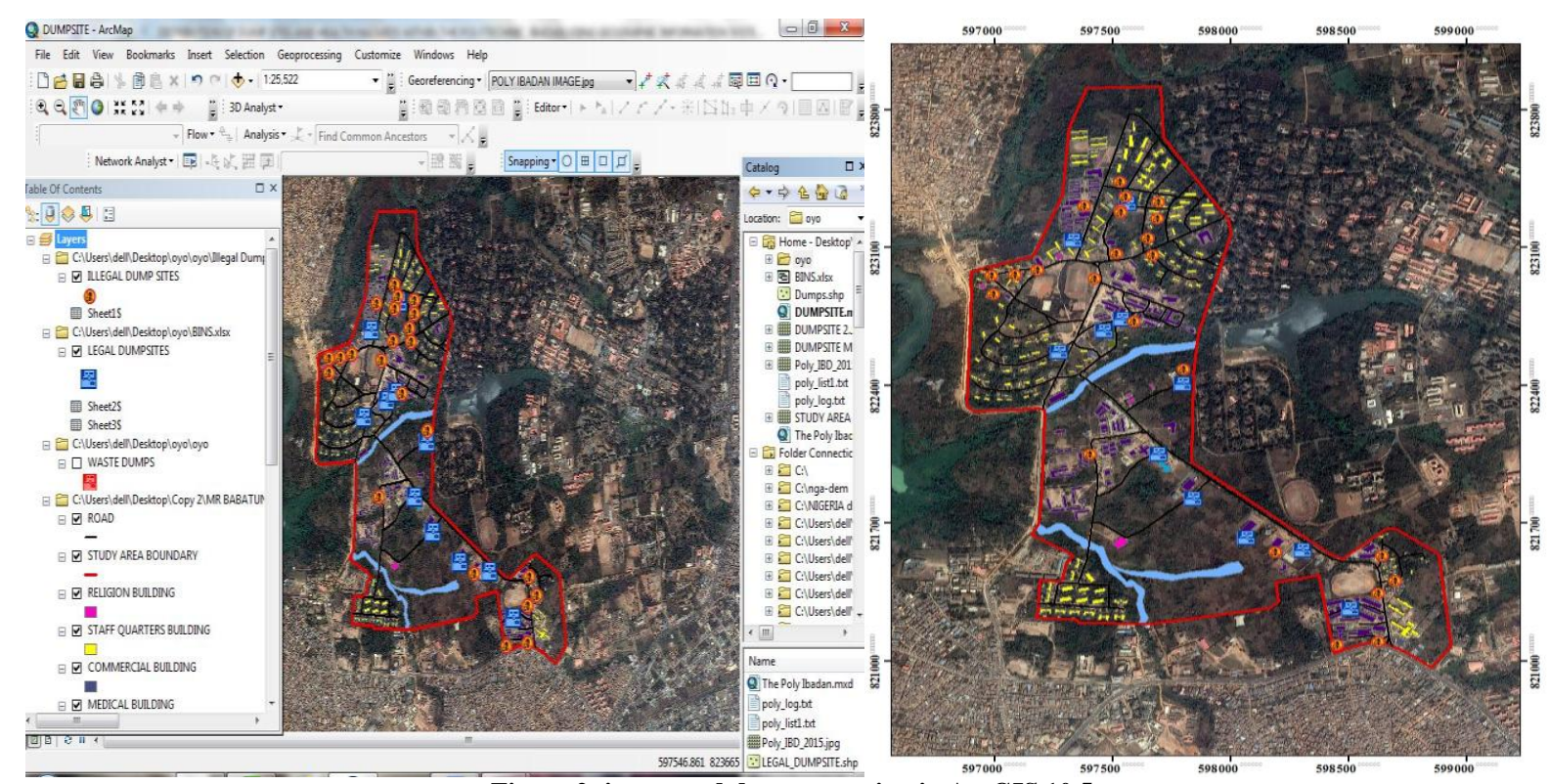

Figure 2: image and data processing in ArcGIS 10.5 


\section{Database Creation}

Database was created using Arc catalogue in ArcGIS 10.5 to create a Geodatabase file for the study where the feature dataset and feature classes were created. Point feature were used to represent dump sites, Line features to represent roads, and waterways, while polygon feature was used to represent all existing buildings within the study area. From the database created, all the existing buildings were categorized according to their usage in the study area such as staff quarters, hostels, classrooms etc.

\section{RESULT}

The results of this study are presented in form of tables, maps and map queries. Figure 3 presents the composite map for the study showing the spatial location of legal and illegal dump sites.
Figure 4 shows the $100 \mathrm{~m}, 300 \mathrm{~m}$ and $160 \mathrm{~m}$ buffer zone of dump sites to the roads, staff quarters and waterways. Figure 5 and 6 presents the spatial query analysis for legal dump sites and illegal dump sites. Figure 7 describes the category and percentage of both the legal and illegal dump sites. Figure 8,9 and 10 presents the buffering analysis of both legal and illegal dump sites to the roads, residential (staff quarters) and waterways. Table 1 is the attribute table created that presents the status and the location description and the spatial coordinates of the legal and illegal dump sites. Thirty-five (35) dump sites (legal and illegal) were within the study area. Table 2 presents the number of legal to illegal dump sites within the study area and table 3 presents the criteria based on the proximity of dump sites to the existing features.

Table 1: Attributes table of dump sites within the study area

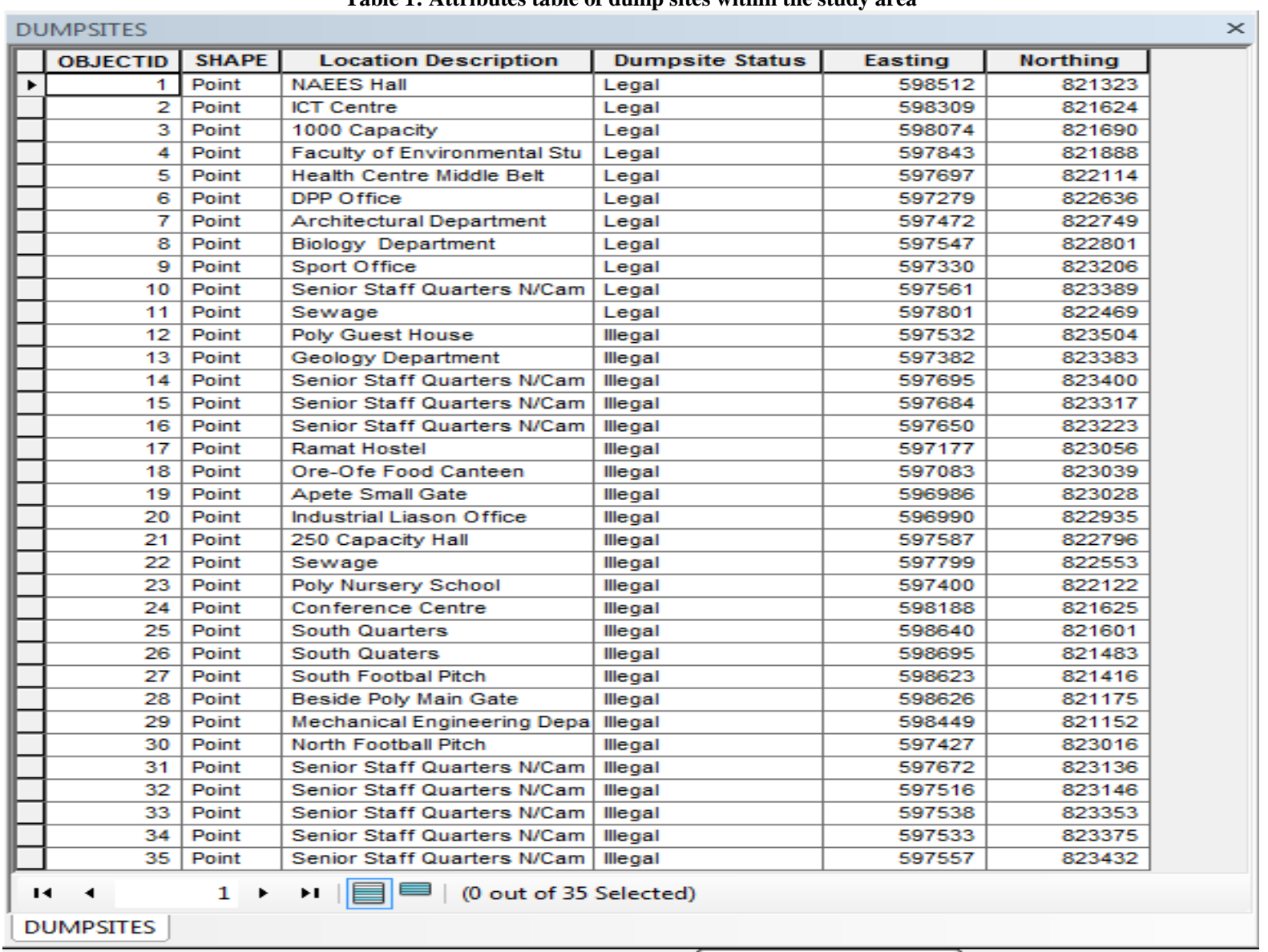


Fatunmibi, Oluwagbemiga et.al. Dump sites location and its health implications within the polytechnic, Ibadan using geographical information system approach.

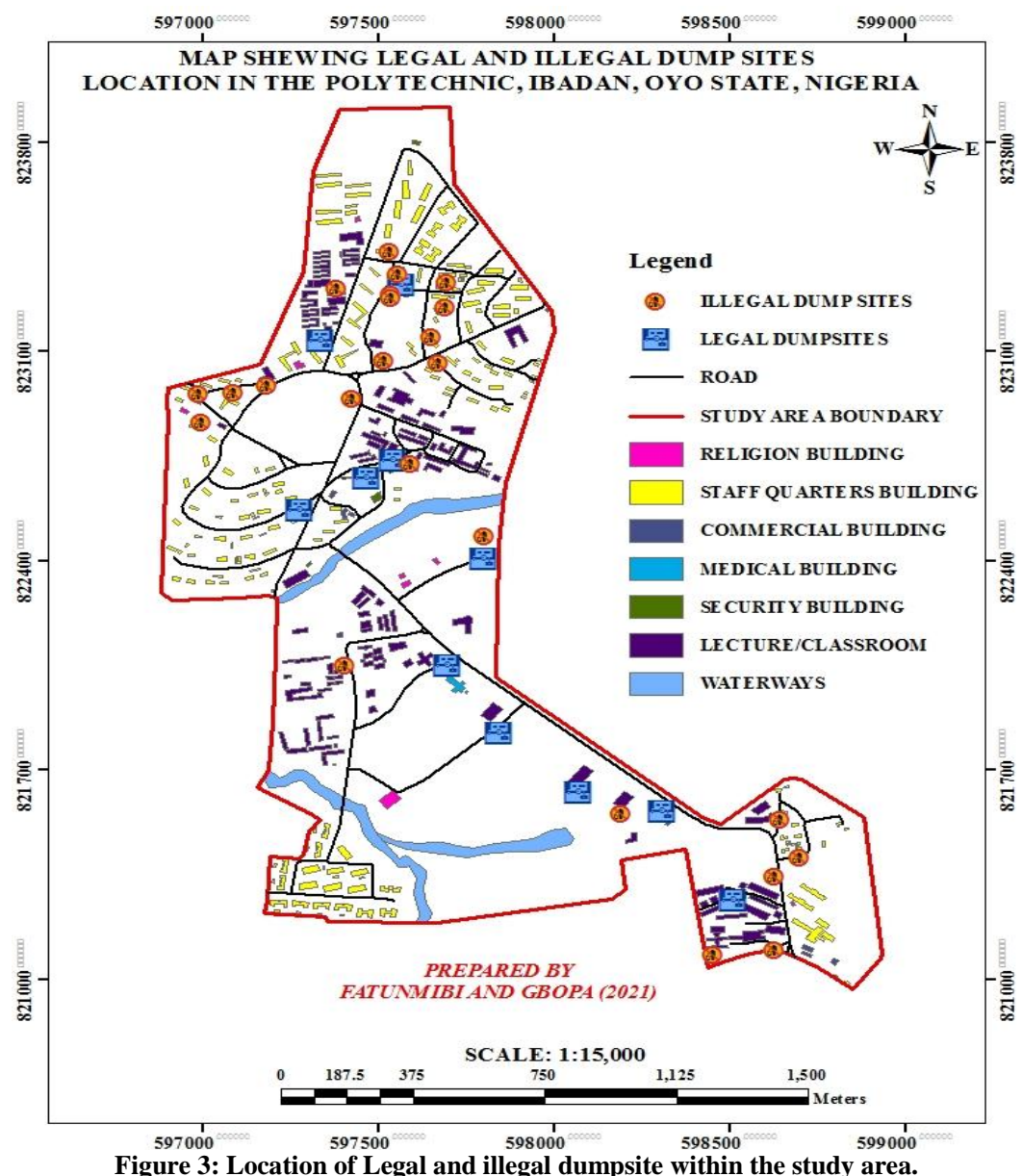

Figure 3: Location of Legal and illegal dumpsite within the study area.

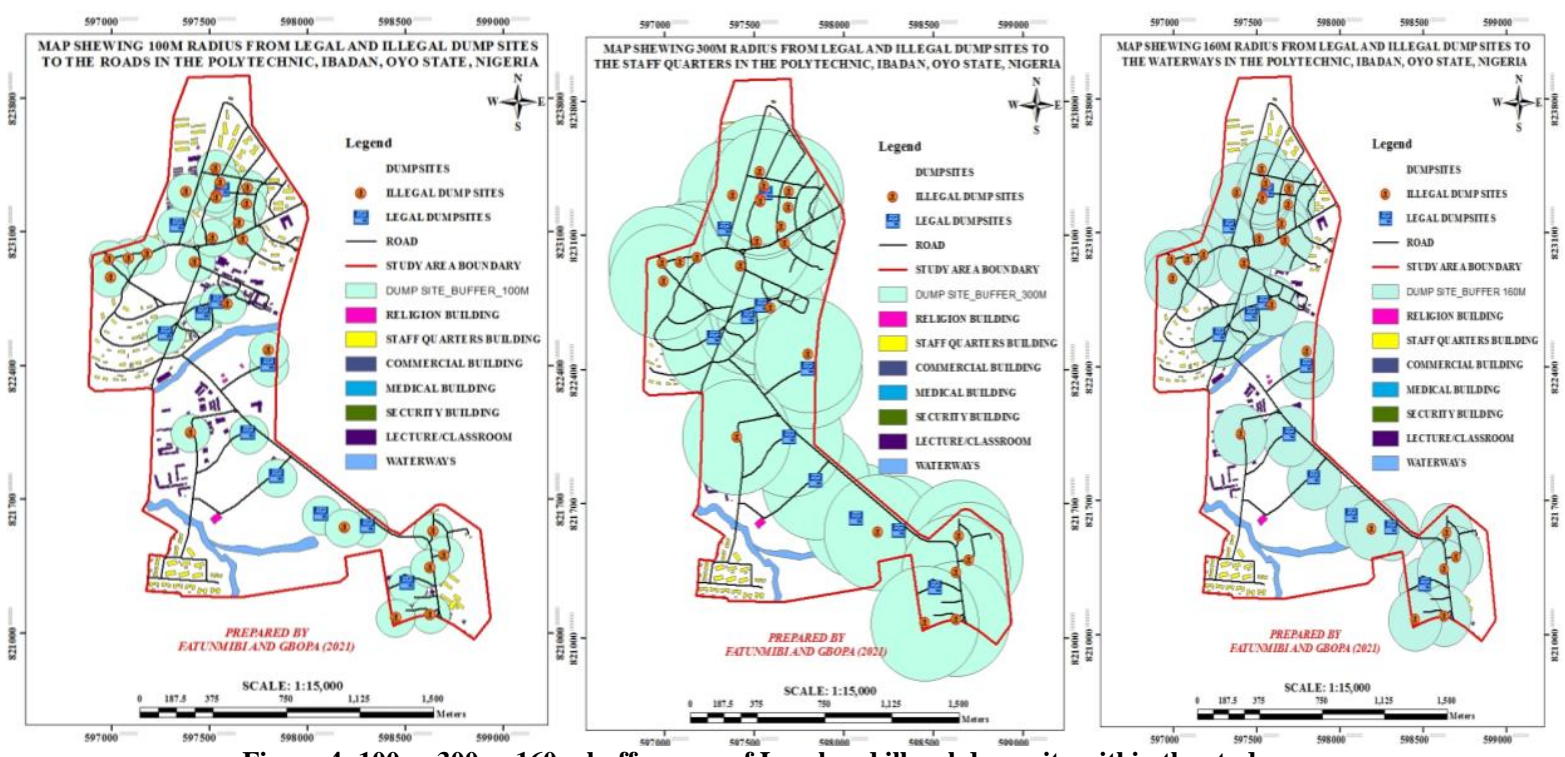

Figure 4: $100 \mathrm{~m}, 300 \mathrm{~m}, 160 \mathrm{~m}$ buffer zone of Legal and illegal dumpsite within the study area.

\section{Geospatial Analysis}

The spatial analysis employed through query was to know the status of dump sites and the spatial location within the study area (figure 5 and 6). Buffering operation and proximity analysis was also done in the ArcGIS 10.5 environment. A buffer of $100 \mathrm{~m}$ was used to determine the proximity of the dump sites to the road since the suitable distance by Environmental Protection Agency (landfill manual, 2006) to the road is between $100 \mathrm{~m}-500 \mathrm{~m}, 300 \mathrm{~m}$ distance was used to the built up area and $160 \mathrm{~m}$ to the waterways (see figure 8-10). 
Fatunmibi, Oluwagbemiga et.al. Dump sites location and its health implications within the polytechnic, Ibadan using geographical information system approach.

\section{Spatial search/Query analysis}

Queries are performed through the attribute data created (table 1). This is done to know the legal and illegal dump sites and their total number in the study area and also to determine the radius of dump sites to the existing features.

Table 2: Dump sites in the Study Area

\begin{tabular}{|l|l|}
\hline Dumpsite status & Number of locations \\
\hline Legal & 11 \\
\hline Illegal & 24 \\
\hline Total & $\mathbf{3 5}$ \\
\hline
\end{tabular}

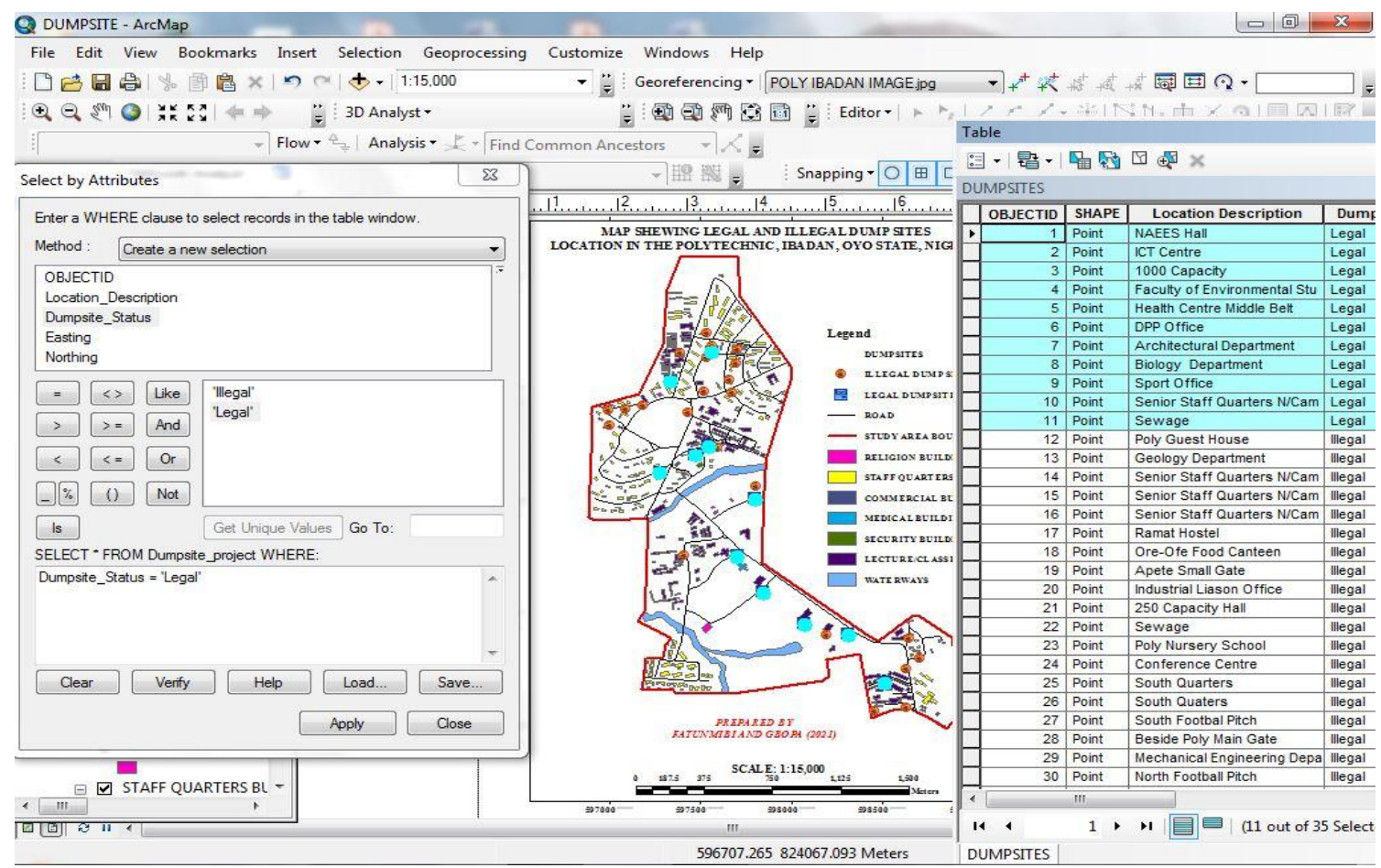

Figure 5: Query showing Legal dumpsite within the study area

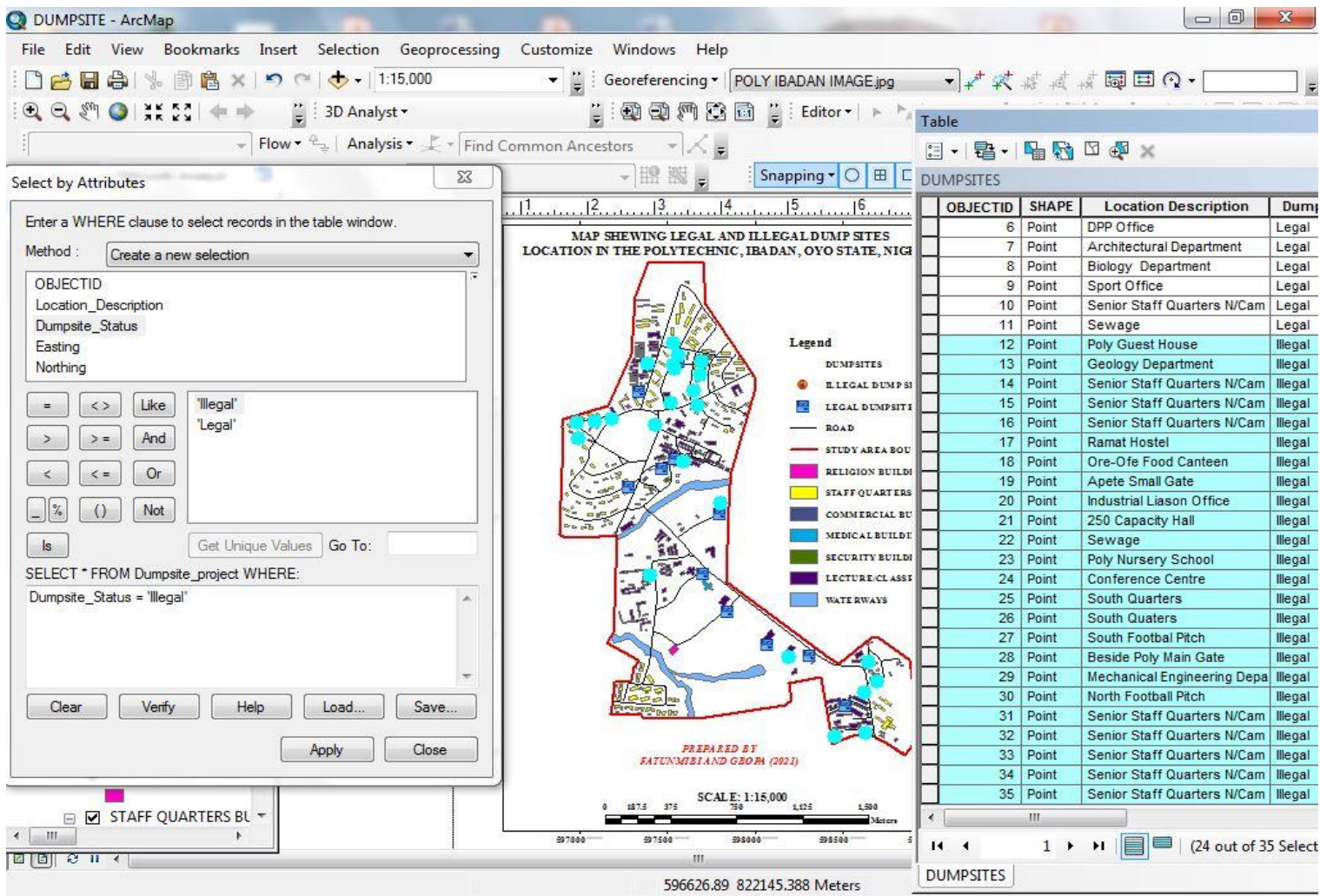

Figure 6: Query showing Illegal dumpsite within the study area 
Fatunmibi, Oluwagbemiga et.al. Dump sites location and its health implications within the polytechnic, Ibadan using geographical information system approach.

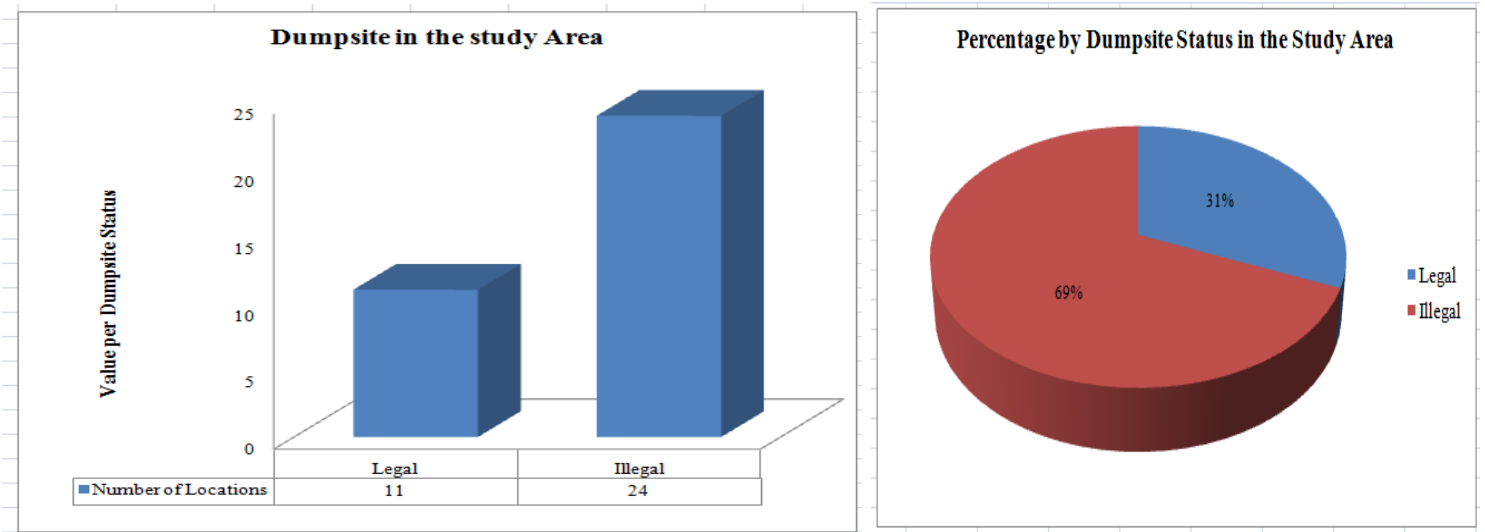

Figure 7: Category and Percentage of legal and illegal dumpsite within the study area

Table 3: Factor criteria table formulated from Environmental Protection Agency (EPA).

\begin{tabular}{|l|l|}
\hline Criteria & Suitable \\
\hline Distance to residential area & $300 \mathrm{~m}$ \\
\hline Distance to road & $100-500 \mathrm{~m}$ \\
\hline Distance to water body & $160-480$ \\
\hline Slope & $0^{0}-5^{0}$ \\
\hline
\end{tabular}

Based on the criteria listed in the table 3 above, queries were performed to verify the conformity of the dumps to the standard.

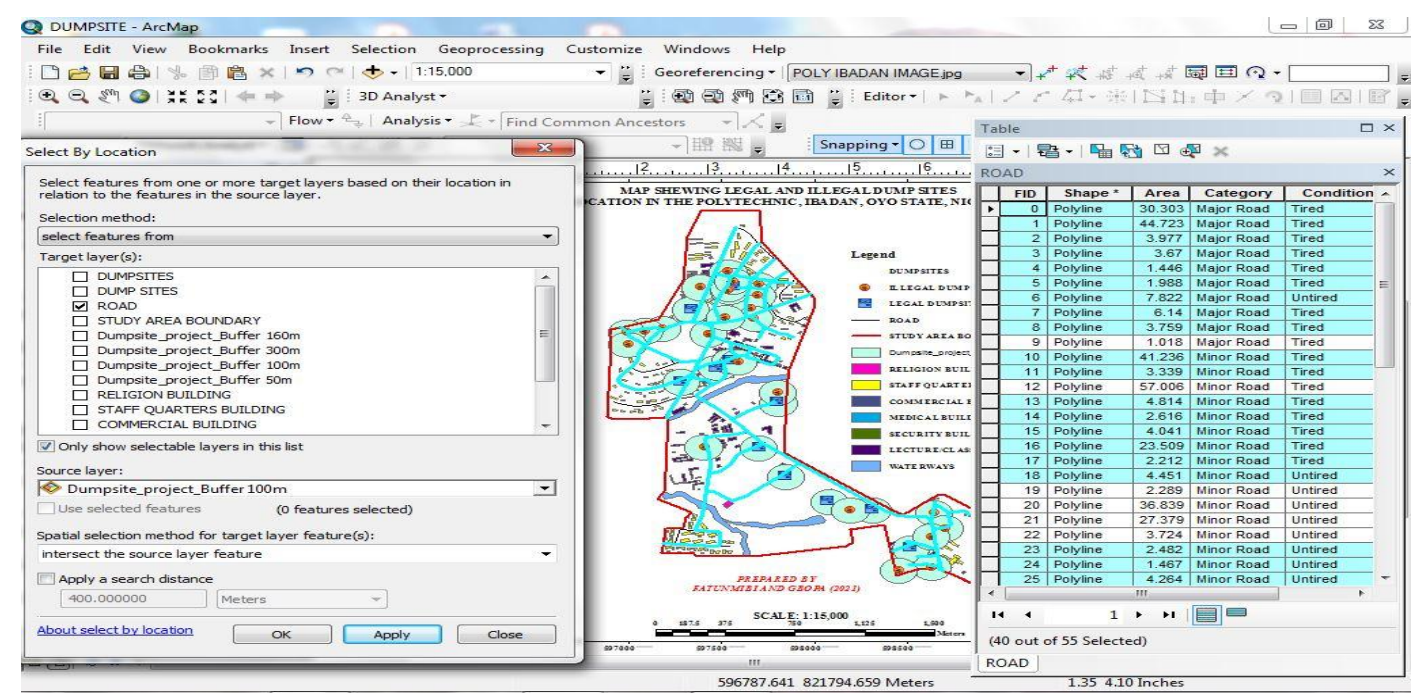

Figure 8: 100 meters buffering of dump sites to roads using selection by location

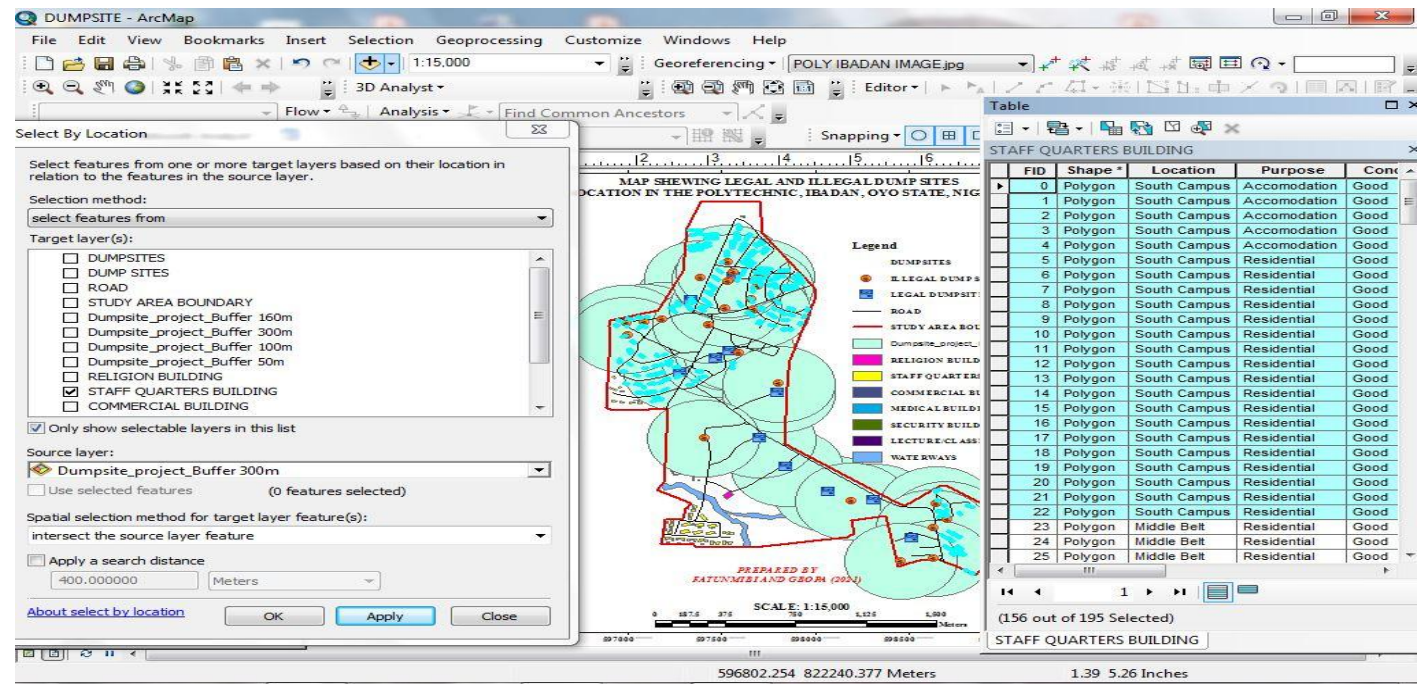

Figure 9: 300 meters buffering of dump sites to Staff Quarters using selection by location 


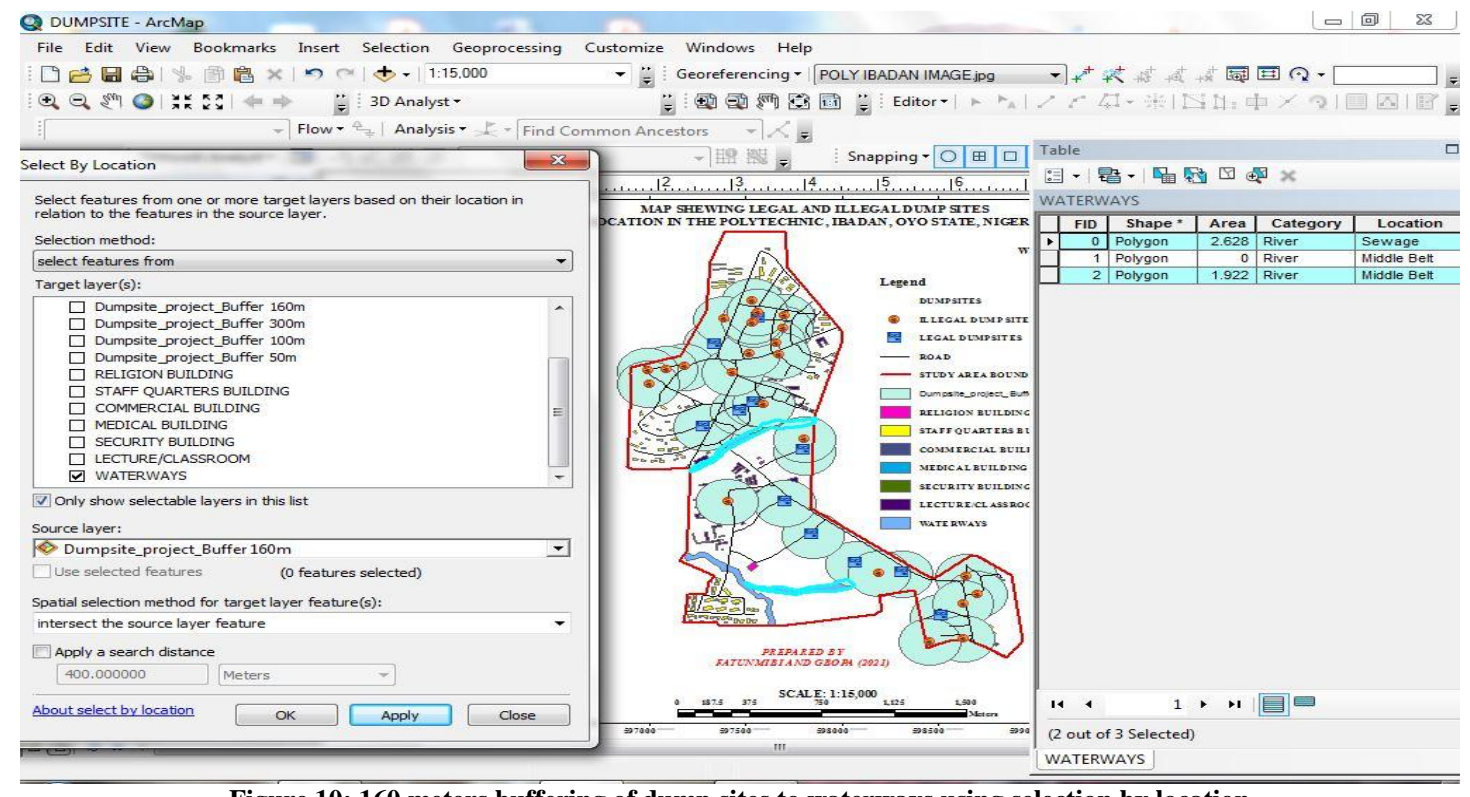

Figure 10: 160 meters buffering of dump sites to waterways using selection by location

\section{DISCUSSION}

From the composite map (figure 3), it shows that a good numbers of illegal dump sites were many in the Northern parts than the middle belt and Southern parts of the institution. From the analysis in the study area, the result shows more illegal dumpsite than legal dumpsite and the result is similar to the result obtained by ${ }^{[21,22]}$. Non availability of dump sites in some areas leads to dropping of refuse anywhere along the road, water bodies and everywhere around the built up areas. Then the illegal dumping of refuse is cluster around staff quarters, hostels and some classrooms. The more the students pass by, the more they litter the ground.

The Spatial Distribution of the legal and the illegal dump sites are shown in figure 3 above, while figure 4 revealed that eleven (11) $31.4 \%$ out of thirty-five (35) dump sites are legal which are properly managed. Figure 5 shows that eight (24) $68.6 \%$ dump sites are not properly managed which are illegal as shown in figure 6 and table 2 and similar to the result obtained by [21, 22].

From the 100meter buffering in figure 7 above, 40 out of $55(72.7 \%)$ routes were selected many of the dump sites were very close to roads where they not only litter the road but constituting nuisance to the environment. Also from figure 8 , with $300 \mathrm{~m}$ radius from the dump sites to the staff quarters, 156 out of $195 \quad(80 \%)$ were selected where they not only destroy the aesthetic value of the areas but also constitute breeding grounds for vectors like mosquitoes, rodents and flies which transmit diseases like malaria, typhoid fever, laser fever and cholera which are part of the highest killer diseases in Nigeria. In some cases, they pollute surface and ground water, hence, exposing inhabitants in the area to the consumption of contaminated water and food which is dangerous to their health. Two (2) waterways are selected; one at the sewage and the other at the middle belt which are the two waterways within the study area.

\section{Health implications of dump site (Legal and Illegal) in the study area}

Adequate evacuation of wastes from the dumping site makes the environment to be hygienic and if not evacuated at the right time, constitutes to health hazards. Indiscriminate dump of refuse constitute breeding grounds for vectors like flies, rodents, mosquitoes, which transmit diseases like typhoid fever, malaria, cholera and laser fever which are part of the killer diseases in Nigeria and most of the African countries. When an environment is not 
hygienic and clean it poses a lot of harms and negative impacts on human especially outdoor workers, workers producing infectious materials while young children get easily contacted and are most vulnerable to this act of ignorance and dirtiness ${ }^{[23]}$.

The outcome of indiscriminate disposal of solid wastes expose human to environmental degradation such as in flooding, drainage obstruction, widespread of infectious diseases, cholera, diarrhea ${ }^{[24]}$, typhoid fever, waterway blockage which leads to infestation of flies, ticks and breeding of mosquitoes that cause malaria and other plagues. Lack of appropriate storage facilities, inadequate waste management and planning, wrong perceptions by residents and non-challant attitudes towards environmental cleaning and sanitation might be a cause of this problem $^{[25]}$.

For the study area, plastic bottles with and without water, waste food, polythene bags with and without water and pieces of papers are the major wastes dropped inside the container or on bare ground and if all these waste decayed together, they produces toxic gas which is release to the atmosphere and the surroundings. Student's as well as staffs and anyone passing by can easily contacted the above named diseases as they inhale the toxic gases and even those selling food that is being consume within the study area need to be far away from unhygienic area or make their environment hygienic since the percentage of illegal dumpsite is high in the study area.

\section{CONCLUSION AND \\ RECOMMENDATIONS}

Geographic Information System has been proven as the best tool to identify location of dump sites within the Polytechnic, Ibadan, Nigeria. Due to the increasing volume of solid waste coupled with poor management stratagem, in The Polytechnics, Ibadan; proliferation of illegal waste dumps has become the order of the day. Although, the distribution identified illegal dumpsite as having the highest record. From the findings in this study, it shows that major waste found in both legal and illegal dump sites were plastic bottles, waste food, polythene bags and pieces of papers. Hence the following were recommended:

i. Waste dumps must be adequately planned, monitored and sited away from infrastructural facilities such as buildings, roads etc.

ii. GIS should be employed as a planning tool for solid waste management. Also, there should be update of the spatial and non-spatial data constantly to support decision making process.

iii. Waste dumps should be properly protected and constantly evacuated to prevent the breeding of pests, flies and rodents as well as pollution.

iv. The institution should establish a sanitation monitoring team to inspect the school environment on a regular basis and dealt with the defaulters accordingly.

v. There should be educative and Enlightenment programs on environmental sanitation to the staffs and as well as the students.

vi. There should be proper awareness creation about the concept of (Reduce, Recycle and Reuse) through media, symposia, workshop, and institutional curricula such that people be enlightened on the advantages and benefit they will rip.

vii. More waste drum points should be established in the institution most especially in the classroom, students' hostels, and staff quarters.

\section{Acknowledgement: None}

Conflict of Interest: None

Source of Funding: None 


\section{REFERENCES}

1. Muhammd, A. M. (2007): An Analysis of Solid Waste Generation and Management in the Federal Capital City Phase I, Abuja, Nigeria. A Ph.D Thesis submitted to the Department of Geography, Bayero Univeristy, Kano.

2. Mabogunje A. L. (1988). A debt of posterity: Reflective on a National Policy on Environmental Management in Sada P.O and Odemero F. O (eds) Environment Issues and Management Evans (Nig) Ltd, pp 17-25

3. Ogunbiyi, A. (2001). Local technology in solid waste management in Nigeria; in Victor and Choji, 2006 "Composting: A viable option for the urban waste management in Nigerian cities". Environ. J. Environ. Stud, 2(3).

4. Environmental Protection Agency (EPA), (2011). Waste-Non-Hazardous; Municipal Solid Waste. U.S. Environmental Protection Agency.

https://archieve.epa.gov/epawaste/nonhaz/m unicipal/web/html/.

5. El-fadel, M., Findikakis, A. N., and Leckie, J. O. (1995). Environmental Impacts of Solid Waste Landfilling. Journal of Environmental Management.

6. WEISS, S. (1974). Sanitary Landfill Technology, London, Noyes Data Corporation.

7. Lee, Y. and Krieger, L. (1990). Landfill Site and Improvement in Design for Sanitary Landfill in Malaysia. In Tong S. L. (eds). Paper presented at the Hazardous Waste Regulation and Management, pp.175-199, Kuala Lumpur.

8. Asian Institute of Technology (AIT) 2004). Municipal Solid Waste Management in Asia. Thailand: AsianRegional Research Program on Environmental Technology (ARRPET), AIT.

9. Asuma, O. (2013). "Leachate characterization and assessment of groundwater and surface water qualities near municipal solid waste dump site in Effurun, Delta State, Nigeria," Journal of Environmental and Earth Sciences, vol. 3, no. 9, pp. 126-135.

10. Sankoh, F. P. and Yan, X. (2013). "Problems of solid waste management in developing urban cities: a case study of freetown, Sierra Leone," American Journal of Environmental Protection, vol. 2, no. 5, pp. 113-120.
11. Engineering Planning and Management Consultant (1996). "Data collection of national study on privatization of solid waste management in eight cities of Pakistan".

12. Aderoju, O. (2014). A Geo-Spatial Approach for Solid Waste Dumpsites for Sustainable Development in Minna, Niger State, Nigeria. IOSR Journal of Environmental Science, Toxicology and Food Technology (IOSR-JESTFT), 8 (10), 16-28.

13. Nigerian Environmental Study Action Team (NEST), (1991). Nigeria's Threatened Environment: A National Profile Ibadan, A NEST Publication.

14. United Nations System in Nigeria, (2001). Nigeria Common County Assessment.

15. Botkin, B.D. and Keller, A.D. (1998). Environmental Science: Earth as a Living Planet. 2nd Edn., USA, John Wiley and Sons Inc.

16. Zakariya'u, M. M. (2010). Problem of Solid Waste Management in Funtua Town. An M.Sc research proposal Submitted to the Department of Geography, Bayero University, Kano.

17. Bellafante G. (1991). Garbage Dictionary, Garbage, Vol 3(1) pp 18.

18. Essays, U. (2018, November 12). Benefits Of Using Gis In Waste Management Environmental. Retrieved January 24, 2020, from

https://www.ukessays.com/essays/environm ental-sciences/benefits-of-using-gis-inwaste-management-environmental-sciencesessay.php.

19. Keir, A. (1997). The Role of GIS in the Privatization of Malaysia Solid Waste Management, 6th ERSI South Asia Users Conference, 8-10 September, Penang, Malaysia.

20. Landfill Manual (2006). Municipal Solid Waste Landfills. United States Environmental Protection Agency US EPA. https://www.epa.gov/landfills/municipalsolid-waste-landfill.

21. L. A. S. Danbuzu, A. I. Tanko, U.A. Ibrahim and M. Ahmed (2014). Spatial Distribution of Solid Waste Collection Points Using GIS Approach In Urban Katsina, Katsina State, Nigeria. American Journal of Engineering Research (AJER) eISSN : 2320-0847 p-ISSN : 2320-0936 Volume-03, Issue-07, pp-107-116 
Fatunmibi, Oluwagbemiga et.al. Dump sites location and its health implications within the polytechnic, Ibadan using geographical information system approach.

22. Paul A. Jegede and Israel O. Taiwo (2019). Spatial Distribution of Dump Sites in the Federal Polytechnic. Quest Journals Journal of Research in Environmental and Earth Science Volume 5 Issue 1 (2019) pp: 6570

23. Yan X, Sankoh FP, Tran Q (2013) Environmental and Health Impact of solid waste disposal in developing cities: A case study of Canville Brook Dumpsite, Freetown, Sierra Leone. J Environ Protection 4: 665-670.

24. Yongsi HBN (2008) Environmental Sanitation Risks on Tropical Urban Settlings: Case Study of household refuse and diarrhea in Yaounde- Cameroon. Int $\mathbf{J}$ Human Soc Sci.
25. Ogunniran Blessing Ifeoluwa (2019). Harmful Effects and Management of Indiscriminate Solid Waste Disposal on Human and its Environment in Nigeria: A Review. Global Journal of Research and Review ISSN 2393-8854. Vol.6 No.1:1, pp. $1-4$

How to cite this article: Fatunmibi, Oluwagbemiga, Gbopa, Adetola Olufunmilayo. Dump sites location and its health implications within the polytechnic, Ibadan using geographical information system approach. International Journal of Research and Review. 2021; 8(5): 467-478. DOI: https://doi.org/10. 52403/ijrr.20210557 